\title{
Risk Assessment of Wild Game Meat Intake in the Context of the Prospective Development of the Venison Market in Poland
}

\author{
Dominika Mesinger*, Aneta Ocieczek \\ Faculty of Entrepreneurship and Quality Science, Gdynia Maritime University, Morska 81-87, 81-225 Gdynia
}

Received: 15 February 2020

Accepted: 27 June 2020

\begin{abstract}
The goal of this work is the critical analysis of premises influencing the concerns typically expressed by Polish consumers over the safety of venison. Risk factors which are indicated in literature as important to the safety of venison in consumers' eyes are discussed, including: 1) trichinosis, 2) genetic modifications, 3) hormones, and 4) toxoplasmosis. The critical analysis of literature data allowed concluding that the aforementioned factors do not increase the risk posed by venison consumption. It was additionally concluded that, in many aspects, the venison is definitely safer meat than meat of the livestock. An overview of literature data demonstrated, however, the potential threat to consumer health posed by wild game meat contamination with heavy metals. For this reason, contents of arsenic, cadmium, lead, and mercury were determined in meat samples of 12 does of red deer (Cervus elaphus L.) from the northern Poland. Results of determinations showed explicitly that the analyzed meat posed no risk associated with the content of heavy metals because contents of arsenic, cadmium, and mercury in 12 samples and lead content in 11 samples were below the detection limit, whereas lead content in one sample was determined at a very low level. In general, the results presented are consistent with literature data, however it needs to be noted that varying conditions of game habitat and factors associated with the hunt can contribute to increased contents of heavy metals in game meat.
\end{abstract}

Keywords: venison, meat, heavy metals, traditional food, red deer

\section{Introduction}

The meat of wild-living animals has for thousands of years been the basic source of wholesome protein and other nutrients, and has added a variety to the human plant food base. As humanity developed, around 10,000 years ago, the acquisition of meat took the

*e-mail: d.mesinger@wpit.umg.edu.pl form of taming and domesticating wild animals. This has allowed man to provide continuous access to food of animal origin. Certain animal breeds were selected and bred, as a consequence of which the production of animal raw materials (meat, eggs, milk, skins) of the best quality was intensified. Despite these efforts, the hunting still functions in all countries in Europe and beyond, although in a different form, and with different purposes and functions [1]. Studies from 1939 provide a definition of hunting, describing it as the art 
of coexisting with living nature and the ability to draw from its goods only to such an extent that it does not violate the source of natural wealth [2]. The oldest and the key function of hunting was and still is providing food, which in some parts of the population will be considered traditional and natural, while in others will be found new. This dualism in the perception of wild game meat can be effectively used to develop this meat market while respecting the principles of sustainable development.

\section{Determinants of Game Meat Consumption}

The term 'tradition' has not been clearly defined to date, however, it has been recognized as a dynamic structure, covering all material and immaterial products of the past generations, which merges the modern generation with the culture of the previous generations. Tradition allows one to get a sense of belonging to a given social group [3]. Narrowing this term to the family tradition, it was found to represent a set of values, attitudes, and behaviors typical of a certain group connected by family ties. Family traditions are passed on to the younger generation, usually informally, which emphasizes the identity of the individual [4]. Very often, they determine the nutritional behaviors of consumers understood as all activities related to the choice of food as well as to the way it is purchased, stored, and prepared for consumption. When describing eating behaviors, consideration should be given to the variety, frequency, and quantity of products consumed by the consumer. The choices made by consumers regarding food are not only driven by family traditions, but also by the cultural background, by the level of their nutritional knowledge, and by their individual preferences [5].

Family traditions have a significant impact on consumer decisions made also regarding traditional foods. Food products recognized by consumers as related to the traditional family cuisine include, among others, these originating from the forest: mushrooms and forest fruit, but also game meat [6]. A characteristic feature of markets in economically developed countries is the fact that, when choosing traditional foods, consumers expect they will be certified. However, there is no such certification regarding forest-derived food products. Consequently, such products as venison are not classified as the traditional or organic foods, while they should, without any doubt, be included among natural foods, especially given the fact that the food market is dominated by highly processed and genetically modified products. It is also worth noting that the trade in forest products measurably contributes to increasing the level of the well-being of local communities, as mentioned by, e.g., Nowacka et al. and Kwiecińska et al. $[7,8]$.

Results of a survey conducted in 2014 by Kwiecińska et al. have shown the family traditions to be the most important factor prompting consumers to buy venison.
These informal messages received from the older generations determine views on hunting and hunters, as well as encourage to the consumption of venison. Survey results indicate also that the strongest impact of family traditions on the willingness to consume venison was recorded in respondents aged over 55 and those living in the countryside. A growing interest in venison was also observed during the holiday periods. Respondents aged 25-34 recognized venison as a product consumed only on the occasion of holidays and were rather little convinced of the need to consume it as part of cultivating family traditions. Young respondents are generally more likely to succumb to the changing trends and fashion than to tradition passed down from generation to generation. This statement, however, fosters some hopes for the development of a traditional product - namely the game meat - with innovative values. In this regard, wild meat can be recognized as a typical market innovation.

Currently, a new trend observed in food consumption is the consumers' interest in broadly understood traditional food and cuisine of different cultures. Eating venison is increasingly characterized as a manifestation of prestige and a desire to emphasize a high social position, rather than continuing certain traditions of the family home [8].

When making a purchase decision, a consumer of food always expects it to be of high quality, with adequate nutritional and sensory values, and safe for health [9]. Even a slight doubt regarding one feature of the product may prevent the consumer from buying it. The most important barriers curbing consumer interest in buying venison have been classified in the literature as: 1) low availability on the market, 2) high price, and 3) concern about both food and health safety. Consumers still declare a negative attitude towards venison consumption associated with the fear of its safety despite being aware that the purchase of venison that had undergone veterinary testing and originates from a proven source, followed by its appropriate heat treatment makes it as safe as other types of meat [10].

Results of research carried out by Kwiecińska et al. (2015) allowed for a preliminary determination of the effect of venison safety perception on consumer purchasing decisions. It was found that consumers declaring the level of their nutritional knowledge as high were less concerned about the potential risk posed by venison consumption. It should be emphasized, however, that such concerns arose in the majority of respondents. The main risks associated with venison intake, which were indicated by the respondents, were: 1) trichinosis, 2) genetic modifications, 3) hormones, and 4) toxoplasmosis [10].

Trichinosis is a zoonotic disease known for ages. Trichinella circulate in both domestic and wild animal populations. Up to 50 cases of trichinosis are recorded in humans in Poland every year. In the European Union, 860,153 wild boars living in the wild were tested in 2012 , and 1,097 of them (i.e. $0.13 \%$ of their population) 
were confirmed to be afflicted with trichinosis. It should also be noted that the infection occurs after ingestion of encysted Trichinella larvae with meat. For this reason, wild boar meat as well as pork should never be eaten raw. The recommendation indicating the need for heat treatment of pork or wild boar meat results from a rational premise, which is that encysted Trichinella larvae found in the muscles die after 15 minutes of heat treatment of the infected meat at a temperature of $65.5^{\circ} \mathrm{C}$. Considering the above, it can be concluded that the risk of trichinosis development is low if all precautions are taken. In addition, the level of safety of both pork and venison is monitored on an ongoing basis, and the meat is tested for Trichinella before being placed on the market. This recommendation results directly from the applicable law in Poland [11].

Genetic modifications of meat are another factor that consumers have identified as a threat to the safety of venison. At the moment, there is no data confirming the game have been genetically modified, whereas the genetic modification of farm animals (pigs in particular) is increasingly common. For example, animals undergo insertion of a human insulin-like growth factor (IGF-1) to obtain a loin weight higher by $30 \%$ and tenderloin weight higher by $10 \%$, as well as a total fat content lower by $20 \%$ of the whole carcass. Generally, the transgenesis aims to increase the carcass slaughter value, and quality of meat and fat. Food products derived from genetically modified organisms must be tested for safety and accordingly labelled. Therefore, despite the low acceptance among consumers, according to the current state of knowledge, these products pose no risk to human health [12].

Hormones perform many important functions in animal organisms: they affect metabolism by coordinating and regulating the work of organs and tissues. Steroid hormones have a significant impact on, inter alia, sexual characteristics, i.e.: estrogens regulate the menstrual cycle in females, while being also responsible for the development of organs and sexual characteristics; whereas androgens ensure the maintenance of spermatogenesis and are responsible for the development of male genital organs. In addition, steroid hormones exhibit the anabolic activity. Elevated levels of hormones in the free form in the natural environment are primarily associated with the use of steroid hormones by people in the treatment of such diseases as: infertility, developmental disorders, cancers, and blood diseases, as well as with complementing natural hormone deficiencies in the body or with using them for the contraceptive effect. In animal production, steroid (sex) hormones are used for anabolic purposes. In practice, their use is limited to their administration to the ruminants, especially when they have low levels of endogenous sex hormones (developmental period). Steroids are used mainly in cattle, but also in sheep, while the advisability of their extensive use has not been confirmed in pigs. Hormones administered orally to animals in their natural form fail to show the desired efficacy. Therefore, they are either implanted to animals in their proper form or given orally in derivative forms. Steroids allow for additional $10 \%$ or even $30 \%$ body weight gains of animals, while improving the feed conversion ratio by approximately $10 \%$. It is worth noting that there is no data indicating any differences between the organoleptic properties of meat obtained from animals stimulated or non-stimulated with hormones. In the case of wild game meat, there is no reasonable fear of an increased hormone content in this meat, as these animals are not fed by humans. In addition, the use of hormones for the sole purpose of stimulating animal growth is strictly prohibited in all Member States of the European Union. Permitted is only the use of certain hormonal compounds prescribed by the veterinarian for therapeutic and zootechnical purposes [13].

Considering concerns expressed by potential consumers of wild game meat over the risk of toxoplasmosis infection, it should be stated that any animal can be a carrier. Toxoplasmosis is a very common disease among cats. In the case of the cervids, studies by Gauss et al. (2006) on 441 cervical serum samples and 161 serum samples of other wild ruminants collected in 1993-2005 in six regions of Spain showed anti-toxoplasmosis antibodies in $15.6 \%$ of the samples tested. However, these authors observed that the number of infections was largely affected by game habitat location. The prevalence of anti-toxoplasmosis antibodies was higher among the animals from Catalonia (42.2\%) compared to other Spanish regions $(8.7 \%)$. The results of the cited study indicate the risk associated with toxoplasmosis infection from wild animals in Spain. Nevertheless, worthy of notice is that infection can occur as a result of consumption of raw or undercooked meat, hence the risk of infection can be almost completely eliminated by the proper consumer education regarding the preparation of venison for consumption. Furthermore, cats have been confirmed to be a major reservoir of $T$. gondii which occupies a special place in the invasion of toxoplasmosis, because seropositive results have been confirmed in 50$70.6 \%$ of their population in Poland. Studies carried out among pigs from the Lublin Province, Poland, showed that $21.2-53 \%$ of the animals had antibodies against toxoplasmosis. Seropositive reactions towards toxoplasmosis have also been revealed in up to $55 \%$ of the Polish cattle population. In contrast, a low percentage of positive results, namely $1-27 \%$ of the population, has been demonstrated in poultry. The above-cited results indicate that venison does not represent a significant risk factor of toxoplasmosis infections among humans compared to other types of meat $[14,15]$.

Consumers did not indicate the presence of heavy metals as a risk factor posed by the consumption of venison, although this issue has been addressed by many authors in the literature. Some results are available from the research conducted with carcasses of wild animals from Poland, which show that the maximum levels were 
significantly exceeded for cadmium in kidneys and liver, for mercury in kidneys, and for lead mainly in muscles and kidneys. It should be emphasized, however, that these values were very diverse. The results obtained in this respect can be an excellent source of information about the contamination of the natural environment inhabited by the game. The extent of game meat contamination with heavy metals should be considered in a broader perspective and take account of the condition of the natural environment affected by the anthropogenic activity. Heavy metals pose an extremely serious threat, especially considering the possibility of their direct transfer across the trophic chain between soil, plants, animals, and people. In addition, they are capable of accumulating at individual stages of the food chain. Their appearance and circulation in the natural environment is due to the natural processes (e.g. bedrock weathering [16], soil-forming processes [16]), but also to the pollution from anthropogenic sources [17], i.e. mining and metallurgy [16, 18, 19]; chemical industry[20]; metallurgical industry [21]; surface runoff from frequently used roads [22, 23]; soil overfertilization with mineral fertilizers [16, 24]; use of large amounts of plant protection agents [16, 24]; and overloading of landfills [25].

Contamination of game meat may also be affected by its contact with the lead cartridge used during hunting, and is then referred to as secondary contamination. For this reason, muscle tissue cannot be a reliable source of information about the presence of this element in the natural environment [26].

Taking into account all the premises indicated as the main reasons underlying consumer concerns regarding the safety of wild game meat consumption, two aspects should be considered. The first is the likelihood of the health hazard, while the second is the level of risk posed by the quantity of game meat consumed. In this context, the risk associated with trichinosis should be perceived the same as that posed by pork consumption. The potential risk associated with genetic modifications and hormonal stimulation in the case of wild meat consumption is many times lower or even null compared to the meat from slaughter animals. On the other hand, the risk associated with the uptake of heavy metals, although not indicated by consumers as a significant problem determining the safety of wild game meat, should be considered in relation to the amount of meat consumed, other nutritional values of meat, and to the general condition of the natural environment the meat derived from [27]. The first thing to ask is, then, whether the amount of venison consumed can affect the severity of risk posed to human health and life due to the level of heavy metals intake.

There is no doubt that venison is lean meat. The growth and development of wild-living game take place naturally, without the interference of a man trying to speed up and optimize the process. Therefore, it seems important and rational to undertake educational activities aimed at increasing the level of consumer knowledge about the benefits of consuming this type of meat. This assumption is of particular importance in the context of data from the Central Statistical Office (CSO-GUS) showing that meat consumption in Poland remained stable over the years 2010-2017 (69.9 and $70.1 \mathrm{~kg} /$ per capita/year, respectively), and that an increase in the consumption of poultry meat per capita (24.6 and $27.5 \mathrm{~kg} /$ year, respectively) and a decrease in pork consumption (respectively 42.2 and $38.2 \mathrm{~kg} /$ year, respectively) were recorded throughout this period. The changes in the structure of meat consumption signaled by the CSO-GUS indicate the growing awareness of the Polish population regarding the importance of the type of food consumed in the context of the development of civilization diseases. Being fatty meat and when consumed in excess, pork may contribute to their development [28]. This fact can be used to promote the consumption of wild game meat for the benefit of both, public health and the natural environment. Efforts should be made to reduce the consumption of meat in total and increase its diversity. There are therefore real opportunities to develop the game meat market while respecting the principles of both sustainable development and healthy nutritional patterns.

Certainly, testing game carcasses for heavy metals is also very important because of the need to control the degree of environmental pollution and the ability of these metals to accumulate in tissues. Hence, the purpose of this work is to assess the level of risks identified as important for consumer decisions likely to stimulate the development of the game meat market as well as to identify and compare the degree of contamination of game meat with heavy metals.

\section{Material and Methods}

The experimental material included 12 samples of meat from 12 does of red deer (Cervus elaphus L.), from the northern part of the Pomeranian Voivodship. Each sample contained mixed meat, originating from different elements of the carcass, i.e. leg, shoulder, saddle, and diaphragm muscle.

The meat samples were taken from the carcasses of individual animals as follows: the animals were obtained in January-February 2019, after shooting, the unskinned carcasses were subjected to post-mortem maturation in cold stores, then the carcasses were skinned, divided into elements and a small sample was cut out from each batch of muscles tested. The sample finally weighed about $300 \mathrm{~g}$ per animal, and it consisted of ham, shoulder, saddle and diaphragm muscle.

Analyses were conducted according to the Polish Standard PN-EN 15763:2010, with the inductively coupled plasma mass spectrometry (ICP-MS) [29]. Detection limits of heavy metals offered by the aforementioned methods were as follows: arsenic 0.010-5.0 mg/kg, cadmium 0.002-1.00 mg/kg, lead $0.010-5.0 \mathrm{mg} / \mathrm{kg}$, and mercury $0.001-5.0 \mathrm{mg} / \mathrm{kg}$. 
Table 1. Contents of heavy metals in meat samples of red deer does.

\begin{tabular}{|c|c|c|c|c|}
\hline Sample & Arsenic content $(\mathrm{mg} / \mathrm{kg})$ & Cadmium content $(\mathrm{mg} / \mathrm{kg})$ & Lead content $(\mathrm{mg} / \mathrm{kg})$ & Mercury content $(\mathrm{mg} / \mathrm{kg})$ \\
\hline 1. & $<0.010$ & $<0.002$ & $<0.010$ & $<0.001$ \\
\hline 2. & $<0.010$ & $<0.002$ & $<0.010$ & $<0.001$ \\
\hline 3. & $<0.010$ & $<0.002$ & $<0.010$ & $<0.001$ \\
\hline 4. & $<0.010$ & $<0.002$ & 0.018 & $<0.001$ \\
\hline 5. & $<0.010$ & $<0.002$ & $<0.010$ & $<0.001$ \\
\hline 6. & $<0.010$ & $<0.002$ & $<0.010$ & $<0.001$ \\
\hline 7. & $<0.010$ & $<0.002$ & $<0.010$ & $<0.001$ \\
\hline 8. & $<0.010$ & $<0.002$ & $<0.010$ & $<0.001$ \\
\hline 9. & $<0.010$ & $<0.002$ & $<0.010$ & $<0.001$ \\
\hline 10. & $<0.010$ & $<0.002$ & $<0.010$ & $<0.001$ \\
\hline 11. & $<0.010$ & $<0.002$ & $<0.010$ & $<0.001$ \\
\hline 12. & $<0.010$ & $<0.002$ & & $<$ \\
\hline
\end{tabular}

Source: report from results of laboratory analyses

Analyses were commissioned to an independent accredited laboratory.

\section{Results and Discussion}

Today, there are no strictly defined standards regarding the admissible contamination levels of wild game meat with heavy metals, therefore its safety is assessed based on standards developed for meat of slaughter animals. Commission Regulation No. 1881/2006 of 19 December 2006 setting maximum levels for certain contaminants in foodstuffs clearly describes these values for meat of slaughter animals (excluding offal - beef, mutton, pork and poultry), which are consequently [30]:

- lead $0,10 \mathrm{mg} / \mathrm{kg}$ of fresh product,

- cadmium $0,050 \mathrm{mg} / \mathrm{kg}$ of fresh product.

There is no restriction for slaughter animals meat regarding the content of arsenic and mercury, however compliance with the ALARA (As Low As Reasonably Achievable) principle should be assumed.

Results of analyses of meat samples from red deer (Cervus elaphus L.) females are presented in Table 1.

Exact contents of arsenic, cadmium, and mercury were not determined in any of the 12 analyzed meat samples, because they were below the detection limit of the method employed. In the case of lead, its content was below the limit of detection in 11 analyzed samples, whereas in one sample it was determined at $0.018 \mathrm{mg} / \mathrm{kg}$. Considering the limits of detection offered by the applied method for lead $(0.010-5.0 \mathrm{mg} / \mathrm{kg})$, it can be explicitly concluded that its content was negligible.

The permissible content of arsenic in meat of slaughter animals is at $0.2 \mathrm{mg} / \mathrm{kg}$ meat. A study conducted by Soler et al. (2016) [31] in the western
Spain demonstrated that the muscle tissue of red deer was the source of $0.00596 \pm 0.00508 \mathrm{mg}$ arsenic $/ \mathrm{kg}$ meat. In turn, a research carried out by Giżejewska et al. in 2017 [32] in the Warmia and Mazury region of Poland, demonstrated arsenic content in red deer tissues at $0.0020 \pm 0.002 \mathrm{mg} / \mathrm{kg}$ meat.

The permissible level of cadmium in meat of slaughter animals has been set at $0.05 \mathrm{mg} / \mathrm{kg}$ meat. Analyses of meat samples from the Croatian wild-living game [33] showed cadmium content at $0.0584 \mathrm{mg} / \mathrm{kg}$ muscles. In turn, meat of red deers from northern Italy had a lower cadmium content, reaching $0.0060 \mathrm{mg} / \mathrm{kg}$ meat [34]. Investigation conducted in Poland, in the Warmia and Mazury Voivodship, demonstrated the highest content of cadmium in meat of red deers, which reached $0.1000 \mathrm{mg} / \mathrm{kg}$ meat [35].

The permissible level of lead in meat of slaughter animals has been set at $0.1 \mathrm{mg} / \mathrm{kg}$ meat. The meat of red deers from different regions of Poland is characterized by very diverse lead levels. The mean lead content in meat of red deers from north-eastern Poland was at $0.1000 \pm 0.09 \mathrm{mg} / \mathrm{kg}$ content, with the lowest determined content reaching $0.0400 \mathrm{mg} / \mathrm{kg}$ meat and the highest one reaching $0.4800 \mathrm{mg} / \mathrm{kg}$ meat, whereas the mean lead content in meat of red deers from the southwestern part of Poland was at $0.1200 \pm 0.10 \mathrm{mg} / \mathrm{kg}$ meat, with the lowest determined value of $0.0400 \mathrm{mg} / \mathrm{kg}$ meat and the highest value of $0.4700 \mathrm{mg} / \mathrm{kg}$ meat. In turn, red deer meat derived from Croatia contained ca. $0.1710 \mathrm{mg}$ lead $/ \mathrm{kg}$ meat [33]. Based on the collected data, it can be concluded that both the environmental conditions and the site of lead gunshot on animal body represent important factors that determine this element content in meat.

The permissible level of mercury in meat of slaughter animals has been set at $0.04 \mathrm{mg} / \mathrm{kg}$ meat. 
A study conducted in Croatia by Lazarus et al. (2014) with meat of the cervids demonstrated it contained ca. $0.00371 \mathrm{mg}$ mercury $/ \mathrm{kg}$ meat. In turn, Albińska et al. (2011) showed mercury content in muscle tissue of roe deers from the Łódź Voivodship in Poland at $0.0011 \pm 0.0007 \mathrm{mg} / \mathrm{kg}$ meat $[33,36]$.

From the above data, including studies carried out at different times and in different places, it appears that - contrary to the popular belief - venison is not highly contaminated with heavy metals. The above literature data indicate show that increased levels of mercury and arsenic were not recorded. On the other hand, the level of cadmium in meat may vary depending on the habitat of the animal and environment contamination. Hence, it may be concluded that meat from slaughter animals living in similar areas may also be equally contaminated with cadmium. Considering lead contamination, the matter is more complex because in the case of wild game meat, its level may be determined by both natural environment conditions but also by gunshot-related factors, including gunshot place on animal body in particular. To avoid the risk posed by the consumption of meat with highly exceeded permissible level of lead, a sufficiently large area of tissue around the place of the gunshot is cut out and disposed of. These pieces of tissue are not placed on the market, but might have been the part of meat tissue analyzed in the cited research.

The results presented in this article differ from literature data, because the conducted analyses showed no risk posed by heavy metals accumulated in venison. It should also be emphasized that these results inscribe into the overall assessment of wild meat safety indicating its low contamination with heavy metals.

Considering the complex nature of the quality and of the safety being its component, it is worth emphasizing that a Pole consumes on average $0.08 \mathrm{~kg}$ of venison per year, which is very little, especially in the aspect of game meat perception as a potential source of heavy metals. Therefore, when converting the above values to the actual quantities of meat consumed, it should be stated that even at increased levels of contamination compared to the permissible levels, the consumption of venison in the amount of $0.08 \mathrm{~kg} /$ per capita/year cannot be treated as a real health risk posed by body exposure to heavy metals [6].

Currently, there is no trend on the Polish market that would reveal venison consumption at a level comparable to pork $(38.2 \mathrm{~kg} /$ per capita/year), poultry (27.6 kg/per capita/year), and even beef $(3.2 \mathrm{~kg} /$ per capita/year) [37]. That is why, considering both the extent of venison contamination with heavy metals and venison intake per capita, contamination of this meat with heavy metals should not be recognized as a factor determining its safety in the opinion of consumers making their purchase decisions regarding meat. At the same time, extensive education of the Polish population is needed regarding the benefits arising from venison consumption.
The management of safety assurance in the marketing of wild game meat takes place in a strictly defined legal manner. Venison intended for consumption must come from animals that: 1) were killed as a result of hunting, in accordance with hunting regulations; 2) were shot in an unrestricted area; 3) were transported directly after shooting to a collection point or an approved processing plant; and 4) have been examined by a competent veterinarian. In addition, animals must not show any pathologic lesions that could affect meat utility for human consumption. If the meat meets the above conditions, the veterinarian carries out a sanitary-veterinary examination, based on which the meat is described as suitable or unsuitable for consumption. The examination includes unskinned and skinned animals and their internal organs, which are evaluated for their consistency, color, and odor. In the case of any uncertainty as to the assessment of any of the mentioned characteristics, the veterinarian will order laboratory tests. For wild boar carcasses, tests for trichinella presence are obligatory. If the carcass being tested does not raise any objections, it is declared safe for human consumption and marked with a pentagon, which contains "PL" in the upper part, the veterinary identification number of the establishment in the middle part, and the EEC symbol in the bottom part. In turn, if the sanitary-veterinary examination shows: presence of trichinosis; inflammation of testicles, intestines or joints; tumors; abscesses; unusual lesions in the liver and / or spleen; foreign bodies in body cavities; excessive amount of gas in the stomach or intestines; discoloration of internal organs; changes in taste, consistency, odor, and color; putrefactive changes; emaciation; swelling; and bone fractures not related directly to the hunting; the meat of such an animal is classified as unsuitable for consumption and a sign showing an equilateral triangle pointing upwards is placed on it, with the letters PL in the upper part and IW in the lower part [38].

Management of game acquisition is more complicated than livestock management because of the difficulty in determining optimal conditions and requirements related to the environment during hunting. Therefore, to minimize the potential threats related to the safety of hunting and the resulting meat, hunters are required to possess complete knowledge of possible environmental hazards, and handle the shot animals with the utmost care for the cleanliness of the carcass. Both the consumption and processing quality of venison is influenced not only by the health status, age or sex of the hunted animal, but also by the correctness of postslaughter operations carried out in the hunting ground. Only the entirety of properly carried out procedures, starting from slaughtering the animals, through the hygiene of their gutting, proper cooling of the carcass, and conditions of its transport to the collection point can guarantee the health safety of the carcass assessed later by a veterinarian [38].

Hunting is part of the management of game populations and helps in maintaining the balance in 
the natural environment. Sustainable development as defined in art. 5 of the Constitution of the Republic of Poland assumes both social and economic development integrating political, economic and social activities, while maintaining natural balance and durability of basic processes in the natural environment so as to guarantee the possibility of satisfying the needs of the present and future generations. An important positive aspect of hunting is the fact that venison combines environmental, social, and economic elements, which makes it food that allows for sustainable consumption [39].

In terms of both nutritional and organoleptic value, venison can offer an alternative to meat from industrial production. Observing the evolution of attitudes and behaviors of modern consumers, it can be stated that the consumers look for natural foods free of chemicals, the presence of which is due to the production process of both raw materials and finished products in the food industry. These premises constitute serious arguments indicating that it is justified to undertake intensive actions aimed at educating consumers in the matter of the safety of wild game meat and its nutritional values [40]. Increasing consumer interest in meat of wild animals and increasing its consumption does not pose an increased risk, and at the same time promotes the development of health-promoting behaviors. Venison is characterized by both its unique taste and a high nutritional value. It is extremely low in fat and cholesterol contents, but rich in high-quality protein. Regular consumption of wild game meat, mainly that of the cervids, has a strong negative correlation with the incidence of cardiovascular diseases [5].

\section{Summary and Conclusions}

It should be noted that the meat of wild-living animals is clean, organic, and free of undesirable chemicals. Wild animals are not exposed to the stress of industrial farming; they are not fed with hormone- nor antibiotic-containing feed; their feed is what they will find and choose; their growth is not artificially driven; they are free to move according to their own will, unlike the farm animals. The animal hunted as a result of a correctly executed shot dies on the spot, therefore it does not experience excessive and unnecessary stress associated with transport to the slaughterhouse. It happens sometimes in the hunting practice, however, that the animal is shot incorrectly or moves away from the shot line at the time of the shot. Such a shooter should be caught up by the hunter and finished in the shortest possible time to cease its suffering.

Likewise meat of slaughter animals, the wild game meat can be contaminated with bacteria, parasites, and pathogenic viruses. However, the threat to the consumer appears only in the event of improper handling, i.e. as a result of improper storage, wrong cooking method or too short processing time.
High meat consumption is indicated to be one of the causes of chronic non-communicable diseases, also called civilization diseases, which include obesity, ischemic heart disease, hypertension, peptic ulcer disease, as well as allergic ailments. Although meat consumption is not the only direct cause of civilization diseases, it significantly contributes to their increased incidence. That is why, it is important to raise public awareness of the necessity to minimize excessive consumption of fatty meat and to increase that of lean meats. At the same time, it is noteworthy that poultry is intensively reared in farm conditions to achieve greater economic profits, which translates into a real increase in the risk posed by the consumption of thus produced meat.

In Poland there is no widespread tradition of venison consumption, hence poor knowledge of this meat raises concerns as to its purchase and consumption. Also, the low availability of venison on the market is not conducive to overcoming consumers' fears and developing positive eating behaviors. This situation applies not only to Poland, because the venison share in the global meat production market is estimated at $0.65 \%$, including $0.24 \%$ in the European market. Low market share means that venison is not and cannot be a competitive alternative to poultry or pork. At the same time, there are rational premises indicating that its market in Poland should develop as a result of implementing the quality doctrine.

Wild game meat consumption is curbed mainly by its price, which places it in a group of luxury goods. Meat of wild animals is definitely more expensive, which is basically justified by the conditions associated with its acquisition. Due to strict legal regulations determining the safety level of venison, part of the carcasses is classified us unfit for consumption and disposed, which makes its production cost-ineffective and its price higher. Another factor determining the high price of this meat is the low dressing percentage of wild game compared to farm animals. However, great attention paid to the safety and the low dressing percentage of game carcasses translates into high quality of venison, which should be emphasized in promotional activities.

Consumers' perception of venison as an exclusive product may be an incentive to buy it as a way to emphasize their social prestige on the one hand, but on the other hand the exclusive nature of this meat boosts its price. Prestigious goods have a high retail margin, which leads to a significant narrowing of the meat market mainly to the affluent customers. In addition, the low availability of venison on the Polish food market is also significantly affected by the high exchange rate of the Euro, which means that it is more profitable to export this meat to the Western markets than to sell it on the domestic market [41]. Nevertheless, the living standards of the Poles are observed to grow, which should contribute to their increased demand for luxury goods. 


\section{Conflict of Interest}

The authors declare no conflict of interest.

\section{References}

1. DZIEDZIC R. Hunting - the essence, culture, functioning, meaning. Studia Wrocławskie. 16, 90, 2014.

2. GARCZYŃSKI W. In defense of the future of Polish hunting. Zakł. Druk. F. Wyszyński i S-ka, Warszawa, 1939.

3. DĄBROWSKA A. Family tradition as a heritage of national culture [publisher:] J. Nikitorowicz, J. Halicki, J. Muszyńska (red.), Intergenerational transmission of cultural heritage. Społeczno-kulturowe wymiary przekazu. Trans Humana, Białystok. 97, 2003.

4. KOWALSKA M. The role of tradition in multi-generational rural families in Lesser Poland. Journal of Agribusiness and Rural Development. 2 (8), 1, 2008.

5. KWIECIŃSKA K., KOSICKA-GEBSKA M., GEBSKI J. Polish consumers' interest in venison as a counterweight to meat from industrial farming animals. Stowarzyszenie Ekonomistów Rolnictwa i Agrobiznesu Roczniki Naukowe. 18, 1, 151, 2017.

6. SCHULP C.J.E., THUILLER W., VERBURG P.H. Wild food in Europe: A synthesis of knowledge and data of terrestrial wild food as an ecosystem service, Ecological Economics. 105, 292, 2014. DOI: 10.1016/j. ecolecon.2014.06.018

7. NOWACKA W.L., WOŹNICKA M., STANISZEWSKI P. The importance of forest benefits for the functioning of the family - case study. Studia i Materiały Centrum Edukacji Przyrodniczo-Leśnej. 16.1[38], 54, 2014.

8. KWIECIŃSKA K., KOSICKA-GĘBSKA M., GĘBSKI J. Impact of family traditions on consumer behavior towards venison. Studia Ekonomiczne. 330, 86, 2017.

9. BARYŁKO-PIKIELNA N. Sensory analysis in ensuring food quality. Przemysł Spożywczy. 12, 25, 1998.

10. KWIECIŃSKA K., KOSICKA-GEBSKA M., GEBSKI J. Security level as a determinant of venison consumption. Problemy Higieny i Epidemiologii. 96 (3), 594, 2015.

11. GLINSKI Z. Zoonotic game diseases. Part I. Trichinosis, rabies, tularemia, lyme disease. Życie Weterynaryjne. 91, 08, 560, 2016.

12. KAJAK-SIEMASZKO K., BORUSZEWSKA K., PRZYBYLSKI W. Genetic modifications of food of animal origin. Żywność. Nauka. Technologia Jakość. 5 (108), 18, 2016. DOI: 10.15193/zntj/2016/108/146.

13. WOŹNIAK B. Steroid hormones - characteristics, use, residues in food of animal origin. Medycyna Wet. 66 (3), 177, 2010.

14. GAUSS C.B.L., DUBEY J.P., VIDAL D., CABEZÓN O., RUIZ-FONS F., VICENTE J., MARCO I., LAVIN S., GORTAZAR C., ALMERÍA S.. Prevalence of Toxoplasma gondii antibodies in red deer (Cervus elaphus) and other wild ruminants from Spain. Veterinary Parasitology. 136 (3-4), 193, 2006. DOI: 10.1016/j.vetpar.2005.11.013

15. SROKA J. Occurrence of Toxoplasma gondii in farm animals. Medycyna Wet. 64, 27, 2008.

16. SHU W., WANG P., ZHAO J., YU X., XU Q. Characteristics, Sources and Risk Assessment of Heavy Metals in the Ganjiang River Basin, China. Pol. J. Environ. Stud. 29 (2), 1849, 2020. doi:10.15244/pjoes/109846.
17. ILIĆ P., NIŠIĆ T., ILIĆ S., STOJANOVIĆ BJELIĆ L. Identifying New 'Hotspot' Heavy Metal Contamination in Industrial Zone Soil. Pol. J. Environ. Stud. 29 (4), 2987, 2020. doi:10.15244/pjoes/113095.

18. LI P., LIN C., CHENG H., DUAN X., LEI K. Contamination and health risks of soil heavy metals around a lead/zinc smelter in southwestern China. Ecotoxicology and Environmental Safety. 113, 391, 2015. DOI: 10.1016/j. ecoenv.2014.12.025

19. LINHUA S., SONGBAO F. Heavy Metals in the Surface Soil around a Coalmine: Pollution Assessment and Source Identification. Pol. J. Environ. Stud. 28 (4), 2717, 2019. doi:10.15244/pjoes/94052

20. SRIVASTAVA N.K., MAJUMDER C.B. Novel biofiltration methods for the treatment of heavy metals from industrial wastewater. Journal of hazardous materials 151 (1), 1, 2008. DOI: 10.1016/j.jhazmat.2007.09.101

21. ILUȚIU-VARVARA D.A. Researching the Hazardous Potential of Metallurgical Solid Wastes. Pol. J. Environ. Stud. 25 (1), 147, 2016. doi:10.15244/pjoes/60178.

22. PIERRI D. Environmental Hazards Resulting from the Use of Public Roads in Krakow, Poland. Pol. J. Environ. Stud. 29 (4), 2803, 2020. doi:10.15244/pjoes/112453.

23. ROLKA E., ŻOŁNOWSKI A.C., SADOWSKA M.M. Assessment of Heavy Metal Content in Soils Adjacent to the DK16-Route in Olsztyn (North-Eastern Poland). Polish Journal of Environmental Studies. 29 (6), 2020. doi:10.15244/pjoes/118384.

24. CAO Q., LIU B., REN Z., XIAO H., CHENG J., XUE W. Temporal Distribution Characteristic and Risk Analysis of Heavy Metals in Greenhouse Vegetable Soils. Polish Journal of Environmental Studies. 29 (3), 2071, 2020. doi:10.15244/pjoes/111318.

25. KASASSI A., RAKIMBEI P., KARAGIANNIDIS A., ZABANIOTOU A., TSIOUVARAS K., NASTIS A., TZAFEIROPOULOU K. Soil contamination by heavy metals: Measurements from a closed unlined landfill. Bioresource Technology. 99 (18), 8578, 2008. doi org/10.1016/j.biortech.2008.04.010

26. SZKODA J., DURKALEC, M., KOŁACZ, R., OPALIŃSKI, S., ŻMUDZKI, J. Content of lead, cadmium and mercury in game tissues. Medycyna Wet. 68 (11), 689, 2012.

27. RUDY M., ŻUREK J., STANISŁAWCZYK R., GIL M., DUMA-KOCAN P. The content of toxic elements in the tissues of wild game based on the results of research from 2003-2017. Medycyna Wet. 75 (04), 203, 2019. DOI: $10.21521 / \mathrm{mw} .6202$

28. MIGDAŁ W. Meat consumption and lifestyle diseases. Żywność. Nauka. Technologia. Jakość. 14 (6), 48, 2007.

29. Polish Standard PN-EN 15763:2010 - "FOODSTUFFS - DETERMINATION OF TRACE ELEMENTS DETERMINATION OF ARSENIC, CADMIUM, MERCURY AND LEAD IN FOODSTUFFS BY INDUCTIVELY COUPLED PLASMA MASS SPECTROMETRY (ICP-MS) AFTER PRESSURE DIGESTION" Publisher: Polish Committee for Standardization

30. COMMISSION REGULATION (EC) No 1881/2006 of 19 December 2006 setting maximum levels for certain contaminants in foodstuffs

31. SOLER F., MORCILLO S. M., CHAVES J., LOPEZ M. P., MIGUEZ M., OROPESA A., SOSA L. Lead, cadmium, mercury and arsenic in muscle of hunted red deer and wild boar from west Spain. Toxicology Letters, 258, S165, 2016. DOI: $10.1016 /$ j.toxlet.2016.06.1623 
32. GIŻEJEWSKA A., SZKODA J., NAWROCKA A., ŻMUDZKI J., GIŻEJEWSKI Z. Can red deer antlers be used as an indicator of environmental and edible tissues' trace element contamination? Environmental Science and Pollution Research. 24 (12), 11630, 2017. DOI 10.1007/ s11356-017-8798-7

33. LAZARUS M., PREVENDAR CRNIĆ A., BILANDŽIĆ N., KUSAK J., RELJIĆ S. Cadmium, lead, and mercury exposure assessment among Croatian consumers of freeliving game. Arhiv za higijenu rada i toksikologiju. 65 (3), 281, 2014. DOI: 10.2478/10004-1254-65-2014-2527

34. CHIARI M., CORTINOVIS C., BERTOLETTI M., ALBORALI L., ZANONI M., FERRETTI E., CALONI F. Lead, cadmium and organochlorine pesticide residues in hunted red deer and wild boar from northern Italy. Food Additives \& Contaminants: Part A. 32 (11), 1867, 2015. DOI: $10.1080 / 19440049.2015 .1087058$

35. FALANDYSZ J., SZYMCZYK-KOBRZYŃSKA K., BRZOSTOWSKI A., ZALEWSKI K., ZASADOWSKI A. Concentrations of heavy metals in the tissues of red deer (Cervus elaphus) from the region of Warmia and Mazury,
Poland. Food additives and contaminants. 22 (2), 141, 2005. DOI: $10.1080 / 02652030500047273$

36. ALBIŃSKA J., GÓRALSKI J., SZYNKOWSKA M.I., LEŚNIEWSKA E., PARYJCZAK T. Mercury in carcasses of wild game originating from the Łódź Voivodeship. Rocznik Ochrona Srodowiska. 13, 525, 2011.

37. Agricultural Statistical Yearbook 2018, GUS 2019, Warszawa.

38. ZIEMBIŃSKA A., KRASNOWSKA G. Ensuring health safety in trade in game carcasses. Żywność. Nauka. Technologia. Jakość. 1 (50), 16, 2007.

39. SKORUPSKI M., WIERZBICKA A. Venison as a source of healthy food - problems and perspectives. Studia i materiały CEPL w Rogowie. 16.38 (1), 171, 2014.

40. HOFFMAN L.C., WIKLUND E. Game and venison-meat for the modern consumer. Meat science. 74 (1), 197, 2006. DOI: 10.1016/j.meatsci.2006.04.005

41. POPCZYK B. Game trading problems [publisher:] Problems of modern hunting in Poland, red. D. Gwiazdowicz, Oficyna wydawnicza G\&P, Poznań, 137, 2012. 
